\title{
Electrochemical Behavior of Ni(II)-Salen at the Mercury Electrode
}

\author{
Pércio Augusto Mardini Farias and Margarida Bethlem Rodrigues Bastos \\ Department of Chemistry, Pontifícia Universidade Católica, Rua Marques de São Vicente 225, 22453-900 Rio de Janeiro, RJ, Brazil \\ Correspondence should be addressed to Pércio Augusto Mardini Farias; pfarias@puc-rio.br
}

Received 4 February 2013; Revised 26 March 2013; Accepted 1 April 2013

Academic Editor: Angela Molina

Copyright ( 2013 P. A. Mardini Farias and M. B. Rodrigues Bastos. This is an open access article distributed under the Creative Commons Attribution License, which permits unrestricted use, distribution, and reproduction in any medium, provided the original work is properly cited.

\begin{abstract}
The complex Ni(II)-salen has been studied using cyclic and square-wave cathodic stripping voltammetry at the static mercury drop electrode in an aqueous media of phosphate and Hepes buffers (at pH 7.0). The resulting voltammograms consist of a totally irreversible one-electron transfer attributable to the coupling of $\mathrm{Ni}(\mathrm{II})$ salen/ $\mathrm{Ni}$ (I) salen via an $\mathrm{EC}$ mechanism. The mean value for the transfer coefficient $\alpha$ in both supporting electrolytes was calculated as $0.35 \pm 0.05$. The amount of reactant adsorbed after $60 \mathrm{~s}$ of accumulation at $-700 \mathrm{mV}$ was calculated to be $2.8 \times 10^{-8} \mathrm{~mol} \cdot \mathrm{cm}^{-2}$. The detection limit for nickel determination was found to be $3.4 \times 10^{-9} \mathrm{~mol} \mathrm{~L}^{-1}$.
\end{abstract}

\section{Introduction}

The effective clinical use of cis-diammine dichloro platinum(II) complex and other platinum complexes in the treatment of human cancer has stimulated studies in the interaction of DNA with different metal complexes. While some metal complexes possess potential antitumor activities, many others are persistent environmental hazards. The understanding of the precise nature of the interaction of different metal complexes with DNA is crucial to better predict their utilization for diverse purposes such as pharmacology, controlling genetic information, and the elucidation of protein-DNA contacts or gene therapy [1].

Several areas of chemistry have taken great interest in salen-type Schiff bases and their complexes with transition metals. This is mainly due to their biological activity [2, $3]$, optical $[4,5]$, catalytic [6-9], chromophoric [10], thermochromic [11], and photochromic [12] properties.

In analytical chemistry, this class of compounds has been used to impregnate ion exchange resins for the study of $\mathrm{Cu}(\mathrm{II}), \mathrm{Co}(\mathrm{II})$, and $\mathrm{Ni}(\mathrm{II})$ complexes [13], in the fluorescent analysis of some amines [14] and amino acids [15] and in solvent extraction of $\mathrm{Ga}(\mathrm{II})$ and $\mathrm{Fe}(\mathrm{III})$ complexes [16]. $\mathrm{Ni}(\mathrm{II})$-selective ion sensors of salen-type Schiff base chelates have also been developed [17].

Recently, it was found that some transition metal complexes, such as manganese [1,18], nickel [19-23], iron [24], ruthenium [25], and copper [26], with ligands of the salen type can selectively modify DNA and RNA [27-29]. The oxidative and reductive chemistry of nickel(II) complexes with Schiff bases of salen type has been studied extensively in organic solvents with different coordinating strength [3037]. In the present work, the electrochemical behavior of $\mathrm{Ni}(\mathrm{II})$-salen (Figure 1) at a mercury electrode in an aqueous phosphate and Hepes buffers ( $\mathrm{pH}$ 7.0) by cyclic and square-wave stripping voltammetry has been examined. The phosphate and Hepes buffers are widely used in studies using biological samples and were chosen for their ability to establish the $\mathrm{pH} 7.0$ in aqueous solutions and they do not interact or affect ions involved in biological reactions. A comparison between the two is that the Hepes has a molecular structure more complex (4-(2-hydroxyethyl)piperazine1-ethanesulfonic acid) than the phosphate buffer, which is prepared at $\mathrm{pH} 7$ using only monosodium phosphate and 


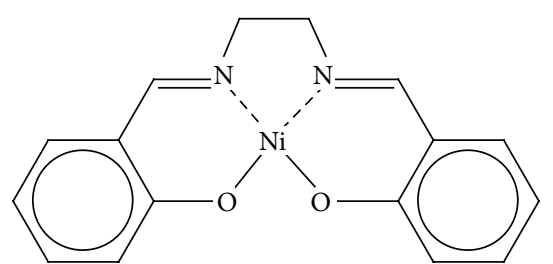

Figure 1: Structure of Ni(II)-salen complex.

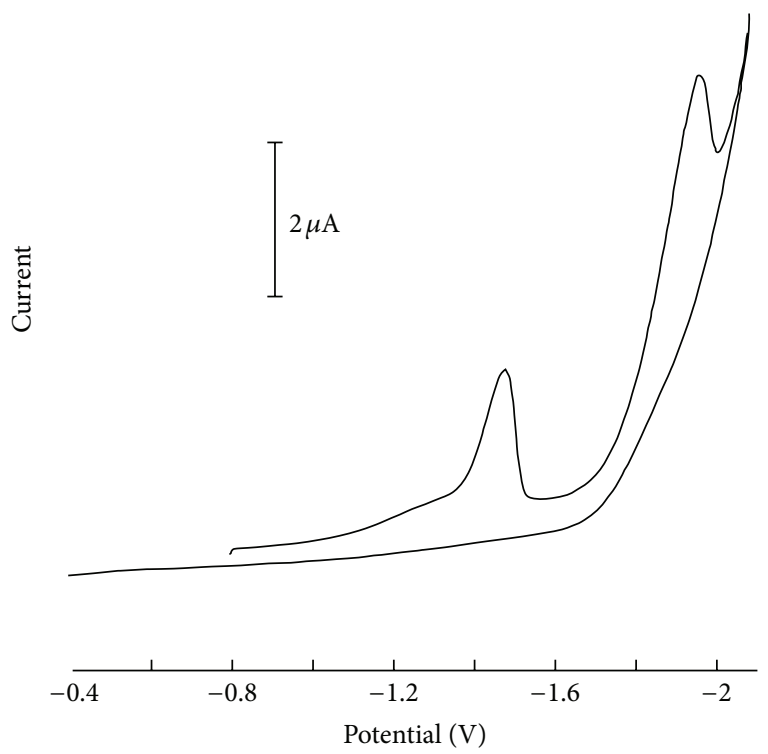

FIGURE 2: Staircase cyclic voltammograms for $1.7 \times 10^{-6} \mathrm{~mol} \mathrm{~L}^{-1}$ of $\mathrm{Ni}(\mathrm{II})$-salen complex in phosphate buffer $\left(0.02 \mathrm{~mol} \mathrm{~L}^{-1}, \mathrm{pH} 7.0\right)$. Equilibrium time: $30 \mathrm{~s}$ at $-800 \mathrm{mV}$. Scan rate: $300 \mathrm{mV} \cdot \mathrm{s}^{-1}$.

its base combined, disodium phosphate. The techniques of cyclic and square-wave voltammetry are highly convenient to understand the redox behavior of $\mathrm{Ni}$ (II)-salen complex in aqueous solution proposed in this paper; in addition square-wave stripping voltammetry technique is very sensitive and ideal for the development of an analytical method for the measurement of $\mathrm{Ni}(\mathrm{II})$-salen at trace levels.

\section{Experimental}

2.1. Apparatus. All measurements were obtained with a BAS$50 \mathrm{~W}$ voltammetric analyzer with a hanging mercury drop electrode. The sample cell $(10 \mathrm{~mL}$ of volume) was fitted with an $\mathrm{Ag} / \mathrm{AgCl}\left(3.0 \mathrm{~mol} \mathrm{~L}^{-1} \mathrm{KCl}\right)$ reference electrode and a platinum wire auxiliary electrode. A magnetic stirrer and a stirring bar provided the convective transport during the preconcentration step on the voltammetric stripping techniques.

2.2. Chemicals and Solutions. All chemicals were of analytical grade. The $\mathrm{Ni}(\mathrm{II})$-salen complex was prepared by refluxing a $0.1 \mathrm{~mol} \mathrm{~L}^{-1}$ solution of nickel acetate with an equal quantity of the ligand salen in ethanol for 2 hours. The precipitate was filtered, washed twice with ethanol and acetone, and dried in a desiccator containing phosphorous pentoxide. The stock solution of the $\mathrm{Ni}$ (II)-salen complex was prepared by dissolving the crystalline complex in dimethylformamide (DMF) up to a solution containing $1.0 \mathrm{mg} \mathrm{L}^{-1}$. Dilutions were made with DMF or with the appropriated stock buffer solution.

The stock buffer solutions of potassium dihydrogen phosphate and 4-(2-hydroxyethyl)-1-piperazine ethanesulfonic acid (Hepes) $\left(0.02 \mathrm{~mol} \mathrm{~L}^{-1}\right)$ were prepared by dissolving the suitable quantities of the reagents (Sigma) in water followed by adding $\mathrm{NaOH}\left(0.2 \mathrm{~mol} \mathrm{~L}^{-1}\right)$ to adjust the desired $\mathrm{pH}$. All solutions were prepared with water distilled and purified by the Milli-Q purification system.

2.3. Procedure. A known volume $(10 \mathrm{~mL})$ of the supporting electrolyte solution $\left(0.02 \mathrm{~mol} \mathrm{~L}^{-1}\right.$ phosphate or Hepes buffers at $\mathrm{pH}$ 7.0) was added to the cell and degassed with nitrogen for $8 \mathrm{~min}$ (and for $30 \mathrm{~s}$ before each square-wave stripping cycle). The preconcentration potential $(-700 \mathrm{mV})$ was applied to the electrode for a selected time, while the solution was stirred. The stirring was then stopped, and after $30 \mathrm{~s}$ the voltammogram was recorded by applying a negative-going potential scan. The scan was terminated at $-1500 \mathrm{mV}$, and the square-wave stripping cycle was repeated with a new mercury drop. After the background stripping voltammograms had been obtained, aliquots of the $\mathrm{Ni}(\mathrm{II})$-salen standards were introduced. The entire procedure was automated, as controlled by the BAS stripping analyzer. Throughout this operation, nitrogen was passed over the solution surface. The staircase cyclic voltammograms started at $-800 \mathrm{mV}$ and the potential was reversed at $-2200 \mathrm{mV}$. All data were obtained at ambient temperature.

\section{Results and Discussion}

The electrochemical reduction of $\mathrm{UO}_{2}$ (II) and $\mathrm{Cu}$ (II)-salen in buffered aqueous solution of phosphate or Hepes at hanging mercury drop electrode (HMDE) was studied in our laboratory $[38,40]$. In connection with such studies, the present work reports an electrochemical behavior of nickel(II) complexed with the Schiff base $\mathrm{N}, \mathrm{N}^{\prime}$ ethylenebis(salicylidenimine), $\mathrm{Ni}(\mathrm{II})$-salen, using cyclic and square-wave voltammetry.

3.1. Cyclic Voltammetry. Cyclic voltammetry (CV) is widely used for the initial characterization of electrochemically active systems. Figure 2 illustrates a typical staircase cyclic voltamogram obtained for $1.7 \times 10^{-6} \mathrm{~mol} \mathrm{~L}^{-1}$ of $\mathrm{Ni}$ (II)-salen complex in an unstirred phosphate $0.02 \mathrm{~mol} \mathrm{~L}^{-1}$ buffer $(\mathrm{pH}$ 7.0). The forward potential scan was started at $-800 \mathrm{mV}$ and its direction was reversed at $-2200 \mathrm{mV}$. A first cathodic peak current was obtained at $-1400 \mathrm{mV}$ and is due to the reduction of $\mathrm{Ni}$ (II)-salen complex. A second cathodic peak, which only appears at a higher scan rate $\left(>200 \mathrm{mV} \mathrm{s}^{-1}\right)$, was observed at $-2000 \mathrm{mV}$. This signal is probably due the disproportionation of $\mathrm{Ni}(\mathrm{I})$-salen (an irreversible chemical reaction) [38, 39]. No 


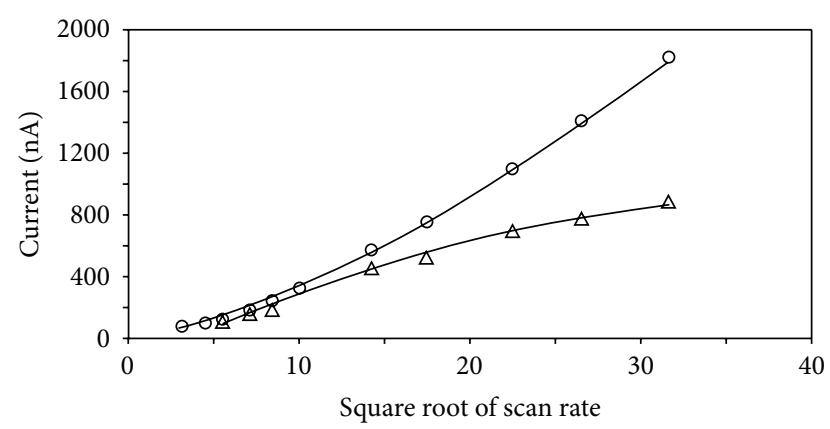

FIGURE 3: Dependence of peak current on square root of scan rate by staircase cyclic voltammetry for $1.7 \times 10^{-6} \mathrm{~mol} \mathrm{~L}^{-1}$ of $\mathrm{Ni}$ (II)-salen complex in phosphate buffer (circle) and Hepes (triangle) buffers (0.02 $\left.\mathrm{mol} \mathrm{L}^{-1}, \mathrm{pH} 7.0\right)$. Equilibrium time of $30 \mathrm{~s}$ at $-800 \mathrm{mV}$.

peak potential was observed in the reverse scan. The absence of peaks in the backward scan can be related to irreversible processes and also to the presence of a chemical step (EC mechanism).

Cyclic voltammograms also were recorded at a series of potential scan rates between 5 and $1000 \mathrm{mV} \mathrm{s}^{-1}$ at a mercury electrode for $1.7 \times 10^{-6} \mathrm{~mol} \mathrm{~L}^{-1}$ of $\mathrm{Ni}(\mathrm{II})$-salen complex. For both phosphate and Hepes aqueous media, a nonlinear relationship between reduction peak current (Ni(II)-salen) $\left(i_{p}\right)$ and the square root of the scan rates $\left(\nu^{1 / 2}\right)$ was observed (Figure 3). A linear plot of $i_{p}$ against $v^{1 / 2}$ should be obtained when the electrode process is a fully reversible or irreversible process at macroelectrodes; deviations from this behavior can be due to radial diffusion, quasi-reversible kinetics, and/or coupled chemical reactions/adsorption [41].

The relationships between $i_{p}$ and scan rate $(\nu)$ also was examined for both supporting electrolytes. A linear plot of $i_{p}$ against $v$ should be obtained when the electrode process is an adsorption-controlled process [42].

For the phosphate buffer, the relationships between $i_{p}$ and $v$ for both ranges of scan rate $\left(5-100\right.$ and $100-1000 \mathrm{mV} \mathrm{s}^{-1}$ ) examined suggested a mixed adsorption- and diffusioncontrolled process at the electrode surface. The plots of $i_{p}$ versus $v$ were linear with different slope values. The slope of the $\log i_{p}$ versus $\log v$ plot over the total range of scan rates examined was 0.72 . This average slope clearly indicates that the process has more than one step. This slope is between the theoretical values of 0.5 and 1.0 for diffusion- and adsorptioncontrolled electrode process, respectively.

In the Hepes buffer, the height of the cathodic peak for the complex in the range of scan rate $\left(5-100 \mathrm{mV} \mathrm{s}^{-1}\right)$ examined is not directly proportional to either the value of the scan rate or the square root of this value. A theoretical treatment [42] of these results suggests that there is a complex overall process controlled by diffusion and adsorption of the $\mathrm{Ni}(\mathrm{II})$-salen species to the electrode surface. From 100 to $1000 \mathrm{mV} \mathrm{s}^{-1}$ the $i_{p}$ versus $v^{1 / 2}$ plot showed a straight line suggesting a diffusion-controlled reduction process. Moreover, the slope of the $\log i_{p}$ versus $\log v$ plot was 0.43 which is very close to

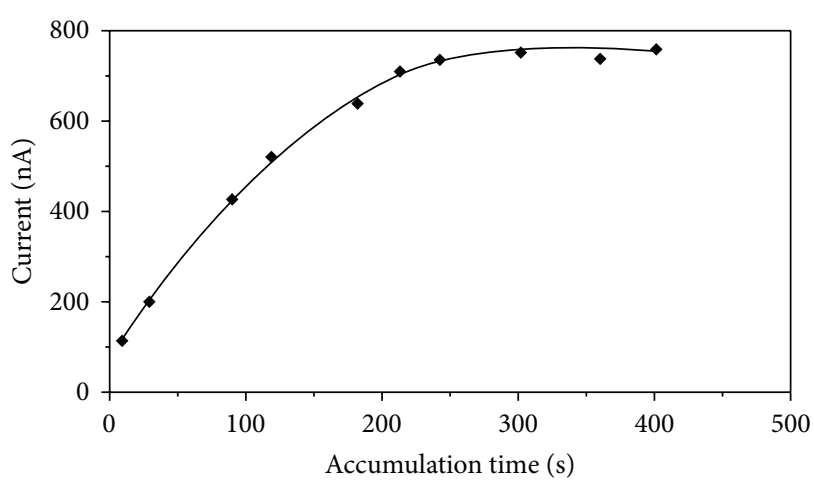

FIgURE 4: The effect of accumulation time on the current of the square-wave stripping peak for $2.1 \times 10^{-7} \mathrm{~mol} \mathrm{~L}^{-1} \mathrm{Ni}(\mathrm{II})$-salen complex in phosphate buffer $\left(0.02 \mathrm{~mol} \mathrm{~L}^{-1}, \mathrm{pH} 7.0\right)$. Accumulation time at $-700 \mathrm{mV}$ with stirring. Potential step height (E-step): $4 \mathrm{mV}$. SW- $a$ : $30 \mathrm{mV}$ and SW- $f: 30 \mathrm{~Hz}$.

the theoretical of 0.5 for the diffusion-controlled electrode process.

The dependence of reduction peak potential $\left(E_{p}\right)$ on the decimal $\operatorname{logarithm}$ of the scan rate $(\log v)$ must be a straight line $[$ slope $=(59 / n \alpha)] \mathrm{mV}$ to allow the determination of the charge coefficient transfer, $\alpha$ [40]. In phosphate buffer when $E_{p}$ is plotted against $\log v$ we obtain a linear relationship (correlation coefficient $=0.999$ ) with slopes of $59 \mathrm{mV}$ and $120 \mathrm{mV}$ for scan rates on the ranges of $10-200 \mathrm{mV} \cdot \mathrm{s}^{-1}(\alpha=$ $0.50)$ and of $200-1000 \mathrm{mV} \cdot \mathrm{s}^{-1}(\alpha=0.25)$, respectively. This demonstrates an increase in the irreversibility of the electrode process with scan rate. Again, the data seems to point out to a process with more than one step.

For the Hepes buffer, the $E_{p}$ against $\log v$ plot was allowed to estimate the value of $\alpha$ as 0.30 over all ranges of scan rates studied.

In the phosphate buffer, from 20 to $100 \mathrm{mV} \mathrm{s}^{-1}$, the $i_{p} / \nu^{1 / 2}$ value is constant. This also establishes the electrode process as diffusion controlled. For Hepes buffer, this $i_{p} / \nu^{1 / 2}$ value is constant for $v>100 \mathrm{mV} \cdot \mathrm{s}^{-1}$.

3.2. Square-Wave Stripping Voltammetry (SWV). SWV also is a powerful technique for electroanalytical purposes and for the elucidation of the redox mechanism and adsorption studies [43]. The relationships of peak potential and current with the square-wave frequency, SW- $f$, and pulse amplitude, SW- $a$, give the characteristics of the redox mechanism [44]. The adsorptive accumulation of the $\mathrm{Ni}$ (II)-salen complex was initially developed by square-wave stripping voltammetry (experimental conditions: $2.1 \times 10^{-7} \mathrm{~mol} \mathrm{~L}^{-1}$ of $\mathrm{Ni}(\mathrm{II})$-salen complex in an phosphate buffer $\left(0.02 \mathrm{~mol} \mathrm{~L}^{-1}, \mathrm{pH} 7.0\right)$; accumulation for $60 \mathrm{~s}$ at $-700 \mathrm{mV}$ with stirring; potential step height (E-step): $4 \mathrm{mV}$; SW- $a$ : $30 \mathrm{mV}$, and SW- $f: 30 \mathrm{~Hz}$ ). The results of the voltammograms showed similar behavior to those obtained on the staircase cyclic voltammetry (Figure 2-forward direction). The first reduction current peak of $\mathrm{Ni}(\mathrm{II})$-salen also was observed at $-1400 \mathrm{mV}$. 


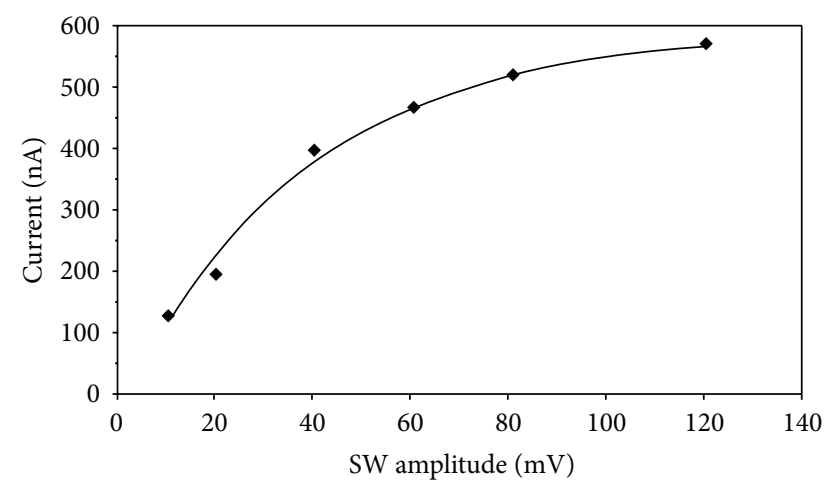

FIGURE 5: The effect of SW amplitude on the current of the squarewave stripping peak for $1.7 \times 10^{-7} \mathrm{~mol} \mathrm{~L}^{-1} \mathrm{Ni}(\mathrm{II})$-salen complex. Other conditions as in Figure 4.

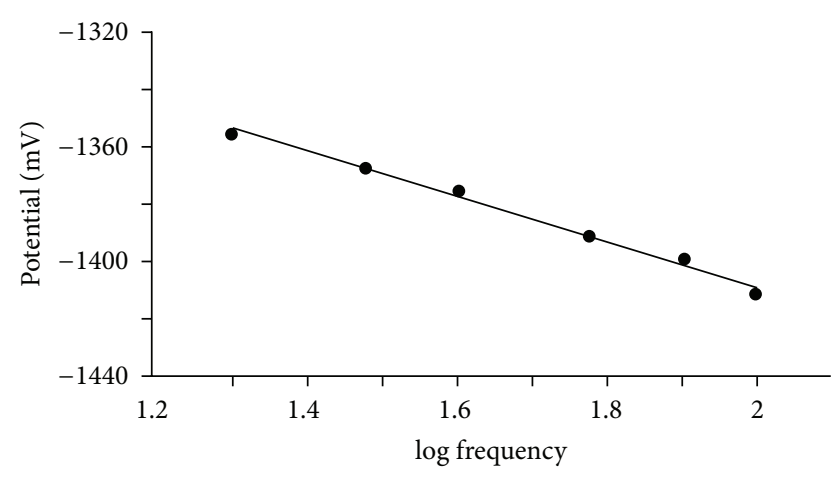

FIGURE 6: The effect of decimal logarithm of the SW frequency on the potential of the square-wave stripping peak for $\mathrm{Ni}(\mathrm{II})$-salen. Other conditions as in Figure 4.

Figure 4 shows the effect of an accumulation time on the square-wave stripping peak current (at $-1400 \mathrm{mV}$ ) of the $\mathrm{Ni}(\mathrm{II})$-salen complex. The current is seen to increase from 0 until leveling off at $210 \mathrm{sec}$. Such time-dependent profiles represent the mercury drop saturated with a stable layer of the complex adsorbed. With higher $\mathrm{Ni}(\mathrm{II})$-salen concentration the reduction current reaches a plateau after a shorter accumulation time.

The relations between the peak current (Ni(II)-salen) and the parameters of the square wave were studied to the better comprehension of irreversibility on the electrode process. The effect of the square-wave amplitude on stripping current is shown in Figure 5. The current increases linearly with the amplitude at first and then levels off. This fact can be characteristic of a totally irreversible redox reaction, but several other systems show similar behavior [45]. Squarewave amplitudes greater than $80 \mathrm{mV}$ yield no additional sensitivity for analytical purposes.

The peak width at half-height was observed and is a crucial parameter for assessing the reversibility or irreversibility of the electrode process. For totally irreversible redox reactions $\Delta E_{p / 2}$ does not depend on the $S W$ amplitude. A separate experiment using the same conditions as Figure 5 also was realized. The results of the voltammograms show

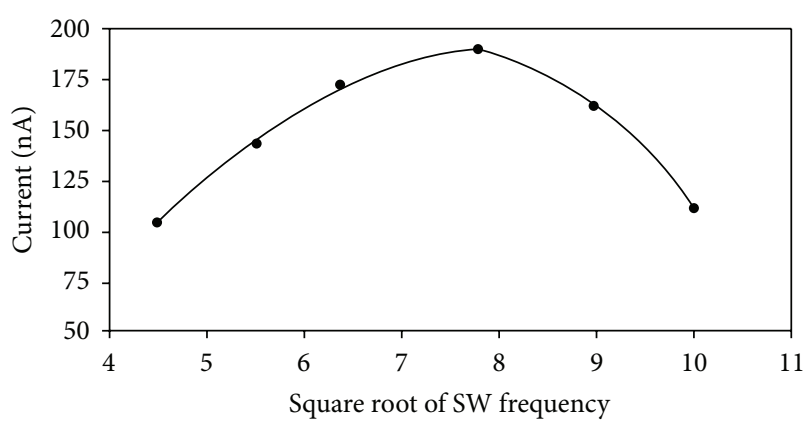

Figure 7: The effect of the square root of the SW frequency on the current of the square-wave stripping peak for $\mathrm{Ni}(\mathrm{II})$-salen. Other conditions as in Figure 4.

which $\Delta E_{p / 2}$, after SW amplitude of $10 \mathrm{mV}$, remains constant. This fact is also characteristic of a totally irreversible redox reaction with the adsorption of the reactant $[45,46]$.

The dependence of the reduction peak current of the $\mathrm{Ni}(\mathrm{II})$-salen complex on the SW amplitude (Figure 5) also shows that the initial slope is $\left(\Delta i_{p} / \Delta a\right)_{a<40}=3.9 \mathrm{nA} \mathrm{mV}^{-1}$. According to the following equation [45]

$$
i_{p}=500 q \alpha n^{2} F a f \Delta E \Gamma,
$$

where $a$ is the SW amplitude, $q$ is the surface area of the electrode, $f$ is the frequency, and $\Delta E$ the scan increment ( $E$ step), the amount of the adsorbed reactant can be calculated from the slope $\Delta i_{p} / \Delta a$, using the values $\alpha=0.37, n=2, q$ $=0.016 \mathrm{~cm}^{2}, f=30 \mathrm{~Hz}, \Delta E$ is $4 \mathrm{mV}$, and $\Gamma$ is the surface concentration of the complex. The calculated amount of the adsorbed reactant is $\Gamma=2.8 \times 10^{-8} \mathrm{~mol} \mathrm{~cm}^{-2}$ with $\mathrm{Ni}(\mathrm{II})$-salen concentration of $1.7 \times 10^{-7} \mathrm{~mol} \mathrm{~L}^{-1}$ in phosphate buffer $(\mathrm{pH}$ 7.0) and using accumulation time of $60 \mathrm{~s}$ at $-700 \mathrm{mV}$.

Precise information about the electrode reaction mechanism arises from the dependence of the reduction current on the SW frequency. At higher frequencies the signal tends to lose its definition as the influence of the charging current becomes increasingly important [47]. Was verified in Figure 6 which the peak potential $\left(E_{p}\right)$ shifts linearly to more negative potential values on the increasing frequency, with indicative for totally irreversible electrode processes and adsorption of the product. The least-squares analysis yielded a slope of $78.8 \mathrm{mV} \cdot \log f^{-1}$ and a correlation coefficient of 0.992 .

The transfer coefficient $(\alpha)$ can be calculated, as the peak potential depends linearly on the logarithm of the SWfrequency as shown in Figure 6. The slope is $\Delta E_{p} / \Delta \log f=$ $59 / n \alpha$ [48]. The half-peak width is independent of the SWfrequency. In theory, these characteristics are attributed to the totally irreversible reduction processes with adsorption of the reactant. Other systems can show this same behavior.

Using large step heights ( $E$-step) greatly increases the net currents, which is also characteristic of irreversible systems [45]. A linear dependence was observed over the range from 2 to $10 \mathrm{mV}$ of step heights. The least-squares analysis yielded a slope of $26.9 \mathrm{nA} \cdot \mathrm{mV}^{-1}$ and a correlation coefficient of 0.988 . A linear dependence of ( $E$-step) on the $E_{p}$ also was observed. 
TABLE 1: Comparison of $\mathrm{Ni}(\mathrm{II})_{-}, \mathrm{Cu}(\mathrm{II})-$, and $\mathrm{UO}_{2}$ (II)-salen complexes in an aqueous medium.

\begin{tabular}{lcccc}
\hline $\begin{array}{l}\text { Metal-salen } \\
\text { complex }\end{array}$ & Electrode & $\begin{array}{c}\text { Supporting electrolyte } \\
(\text { at pH 7.0) }\end{array}$ & $\begin{array}{c}\text { Detection limit } \\
\left(\mathrm{mol} \mathrm{L}^{-1}\right)\end{array}$ & Cathodic peak potential, $E_{p c},(\mathrm{mV})$ \\
\hline Nickel & Hanging mercury drop & Hepes and phosphate & $3.4 \times 10^{-9}$ & -1400 and -2000 \\
Copper [38, 39] & Hanging mercury drop & Phosphate & $1.0 \times 10^{-8}$ & $-160,-530,-990$ and -1100 \\
Uranyl [38, 40] & Hanging mercury drop & Hepes & $1.0 \times 10^{-8}$ & $-590,-950$ and -1140 \\
\hline
\end{tabular}

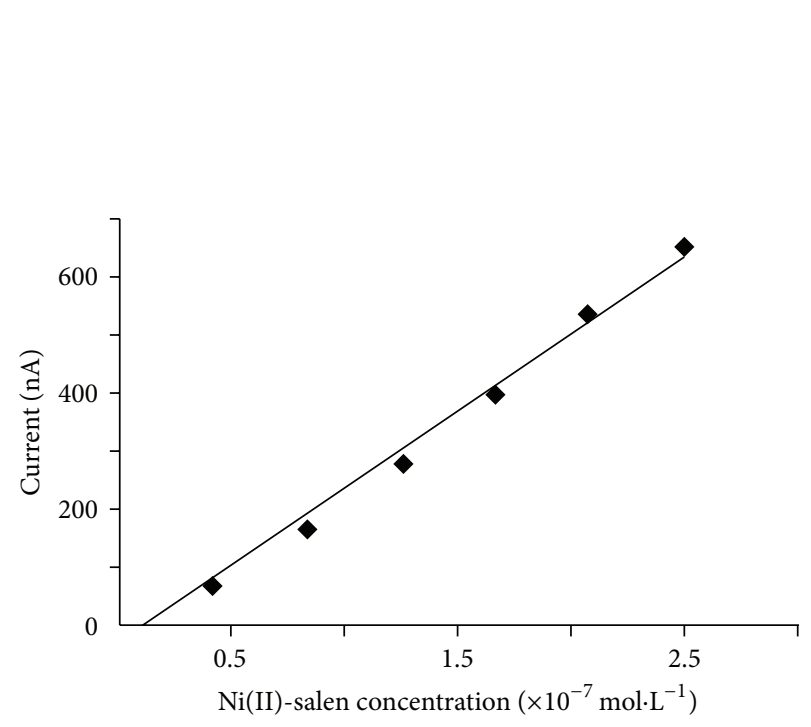

(a)

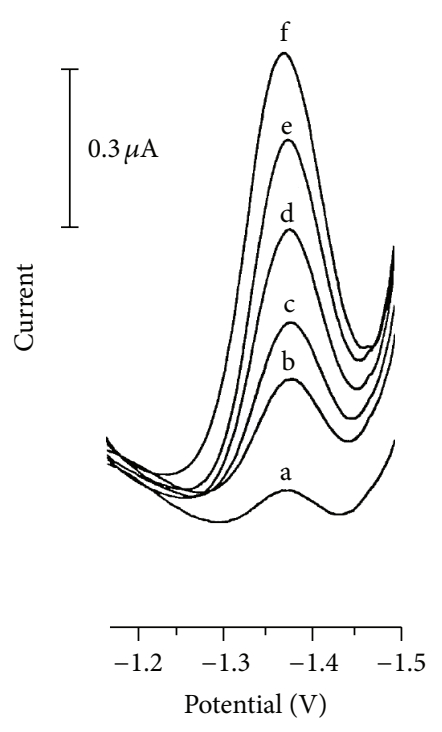

(b)

FIGURE 8: Square-wave stripping voltammograms (b) obtained for solutions of increasing Ni(II)-salen concentration from $4.2 \times 10^{-8}$ to $2.5 \times$ $10^{-7} \mathrm{~mol} \mathrm{~L}^{-1}(\mathrm{a}-\mathrm{f})$. Other conditions as in Figure 4 . Also shown is the resulting calibration plot (a).

The least-squares analysis yielded a slope of -6.8 and a correlation coefficient of 0.993 .

The effect of the square root of the SW-frequency on the peak current of the $\mathrm{Ni}$ (II)-salen complex also was evaluated (Figure 7). The highest peak current was observed using a frequency of approximately $60 \mathrm{~Hz}$.

Adsorptive stripping square-wave analysis has been shown as an important method in trace analysis because of its broad scope of applications and relative simple instrumentation. It was established that the $\mathrm{Ni}$ (II)-salen complex adsorbs at the electrode surface and by accumulation of the complex at $-700 \mathrm{mV}$ the detection of lower concentration is possible. The sensitivity of the square-wave stripping voltammetric response increases with accumulation time and is dependent on the character of the electrode process. Figure 8 shows the voltammograms obtained by varying the $\mathrm{Ni}(\mathrm{II})$-salen concentration from $4.2 \times 10^{-8}$ to $2.5 \times 10^{-7} \mathrm{~mol} \mathrm{~L}^{-1}$. The resulting calibration curve, shown as the inset, is seen to be linear up to $2.5 \times 10^{-7} \mathrm{~mol} \mathrm{~L}^{-1}$ (correlation coefficient $=0.987)$. The detection limit was estimated to be $3.4 \times$ $10^{-9} \mathrm{~mol} \mathrm{~L}^{-1}(\mathrm{~S} / 2 \mathrm{~N})$ with $10 \mathrm{~s}$ of accumulation time.

Table 1 compares the voltammetric behavior of $\mathrm{Ni}(\mathrm{II})$-, $\mathrm{Cu}(\mathrm{II})-$, and $\mathrm{UO}_{2}(\mathrm{II})$-salen complexes in an aqueous medium.

\section{Conclusions}

In the phosphate buffer, the electrode process seemed to be a mixed adsorption- and diffusion-controlled one, whereas in the Hepes buffer a diffusion-controlled electrode process takes place. These results indicate that $\mathrm{Ni}(\mathrm{II})$-salen and the product of its reduction adsorb at the electrode surface with a one-electron reduction through an EC mechanism. Thus the following redox reaction could be suggested:

$$
\begin{gathered}
\text { (Ni(II) salen) ads }+\mathrm{e}^{-} \longleftrightarrow(\mathrm{Ni}(\mathrm{I}) \text { salen }) \text { ads } \\
(\mathrm{Ni}(\mathrm{I}) \text { salen }) \text { ads } \longrightarrow \text { Final products. }
\end{gathered}
$$

Similar results were obtained by Sweeny and Peters [49] using $\mathrm{CV}$, organic supporting electrolyte, and glassy carbon as working electrode. Azevedo et al. [50] reported that in organic media the reduction of the $\mathrm{Ni}$ (II)-salen complex is with one-electron, diffusion-controlled, and reversible reduction process. In addition, the present study describes an effective assay for the determination of trace levels of nickel(II) in presence of salen. The detection limit of $3.4 \times$ $10^{-9} \mathrm{~mol} \mathrm{~L}^{-1}$ is comparable to that seen for other adsorptive stripping methods $[39,40]$. The $\mathrm{Ni}(\mathrm{II})$-salen polymeric film could be applied as a sensor in the determination of dissolved 
oxygen, dipyrone and as an electrochemical energy storage system [51-53]. As the solution of $\mathrm{Ni}(\mathrm{II})$-salen in DMF is water-soluble, we are trying to study the effect of the complex solution on DNA cleavage. This metal complex can also be immobilized on a bismuth film/glassy carbon surface or used to modify a carbon paste electrode in order to study its interactions with DNA.

\section{Acknowledgments}

The authors gratefully acknowledge the CNPq and CNEN of the Government of Brazil and PUC-Rio for support of this work. In addition, they thank J. C. Moreira and M. Lovric for their helpful discussion. The experimental assistances of A. B. Neves and A. T. da Silva are also appreciated.

\section{References}

[1] S. S. Mandal, N. V. Kumar, U. Varshney, and S. Bhattacharya, "Metal-ion-dependent oxidative DNA cleavage by transition metal complexes of a new water-soluble salen derivative," vol. 63, no. 4, pp. 265-272, 1996.

[2] V. A. Soloshonok and T. Ono, "The effect of substituents on the feasibility of azomethine-azomethine isomerization: new synthetic opportunities for biomimetic transamination," Tetrahedron, vol. 52, no. 47, pp. 14701-14712, 1996.

[3] A. A. Hassan, "Chemical interactions between tetracyanoethylene and s-methyldithiocarbazate as well as azomethine derivatives," Phosphorus Sulfur and Silicon and the Related Elements, vol. 101, no. 1-4, pp. 189-196, 1995.

[4] G. A. Shagisultanova, I. A. Orlova, and Y. F. Batrakov, "Photosensitive polymers based on bis(salicylidene)ethylenediamine complexes of copper(II) and palladium(II)," The Russian Journal of Applied Chemistry, vol. 68, no. 4, pp. 567-569, 1995.

[5] K. Bhat, K. J. Chang, M. D. Aggarwal, W. S. Wang, B. G. Penn, and D. O. Frazier, "Synthesis and characterization of various schiff bases for non-linear optical applications," Materials Chemistry and Physics, vol. 44, no. 3, pp. 261-266, 1996.

[6] R. I. Kureshy, N. H. Khan, S. H. R. Abdi, and A. K. Bhatt, "Asymmetric catalytic epoxidation of styrene by dissymmetric $\mathrm{Mn}(\mathrm{III})$ and $\mathrm{Ru}(\mathrm{III})$ chiral Schiff base complexes synthesis and physicochemical studies," Journal of Molecular Catalysis A, vol. 110, no. 1, pp. 33-40, 1996.

[7] G. L. Estiú, A. H. Jubert, J. Costamagna, and J. Vargas, "UV-visible spectroscopy in the interpretation of the tautomeric equilibrium of N,N/(bis-3,5-di-bromo-salicyliden)-1,2diaminobenzene and the redox activity of its $\mathrm{Co}(\mathrm{II})$ complex. A quantum chemical approach," Journal of Molecular Structure, vol. 367, no. 1-3, pp. 97-110, 1996.

[8] M. A. Ischay, M. S. Mubarak, and D. G. Peters, "Catalytic reduction and intramolecular cyclization of haloalkynes in the presence of nickel(I) salen electrogenerated at carbon cathodes in dimethylformamide," Journal of Organic Chemistry, vol. 71, no. 2, pp. 623-628, 2006.

[9] E. Dunach, A. P. Esteves, M. J. Medeiros, D. Pletcher, and S. Olivero, "The study of nickel(II) and cobalt(II) complexes with a chiral salen derivative as catalysts for the electrochemical cyclisation of unsaturated 2-bromophenyl ethers," Journal of Electroanalytical Chemistry, vol. 566, no. 1, pp. 39-45, 2004.
[10] K. Nakanishi and R. Crouch, "Application of artificial pigments to structure determination and study of photoinduced transformations of retinal proteins," Israel Journal of Chemistry, vol. 35, no. 3-4, pp. 253-272, 1995.

[11] J. A. Tenon, M. Carles, and J. P. Aycard, "N-Méthyl succinimide," Acta Crystallographica Section C, vol. 56, no. 5, pp. 568-569, 2000.

[12] S. H. Alarcón, A. C. Olivieri, A. Nordon, and R. K. Harris, "Solid-state electronic absorption, fluorescence and13C CPMAS NMR spectroscopic study of thermo- and photochromic aromatic Schiff bases," Journal of the Chemical Society, vol. 2, no. 11, pp. 2293-2296, 1996.

[13] S. Samal, R. R. Das, D. Sahoo, S. Acharya, R. L. Panda, and R. C. Rout, "Chelating resins. III. Synthesis, characterization, and capacity studies of formaldehyde-condensed phenolic Schiff bases derived from 1,2-diamines and hydroxy benzaldehydes," Journal of Applied Polymer Science, vol. 62, no. 9, pp. 1437-1444, 1996.

[14] T. K. Hwang, J. N. Miller, D. T. Burns, and J. W. Bridges, "Determination of primary amines by means of fluorescent schiff base derivatives," Analytica Chimica Acta, vol. 99, no. 2, pp. 305-315, 1978.

[15] J. Hayashi, M. Yamada, and T. Hobo, "Chemiluminescence flowinjection method for the determination of amino acids based on Schiff base formation in sodium(2-ethylhexyl)sulphosuccinate reversed micelles," Analytica Chimica Acta, vol. 259, pp. 67-72, 1992.

[16] S. Abe, J. Mochizuki, and T. Sone, "Liquid-liquid extraction of iron(III) and gallium(III) with macrocyclic Schiff bases containing bisphenol A subunits," Analytica Chimica Acta, vol. 319, no. 3, pp. 387-392, 1996.

[17] A. K. Jain, V. K. Gupta, P. A. Ganeshpure, and J. R. Raisoni, "Ni(II)-selective ion sensors of salen type Schiff base chelates," Analytica Chimica Acta, vol. 553, no. 1-2, pp. 177-184, 2005.

[18] S. S. Mandal, U. Varshney, and S. Bhattacharya, "Role of the central metal ion and ligand charge in the DNA binding and modification by metallosalen complexes," Bioconjugate Chemistry, vol. 8, no. 6, pp. 798-812, 1997.

[19] M. Sakamoto, Y. Nishida, A. Matsumoto et al., "Nickel(II)lanthanide(III) complexes of the dinucleating ligand N,N'bis(3-hydroxysalicylidene)ethylenediamine," Journal of Coordination Chemistry, vol. 38, pp. 347-354, 1996.

[20] J. R. Morrow and K. A. Kolasa, "Cleavage of DNA by nickel complexes," Inorganica Chimica Acta, vol. 195, no. 2, pp. 245248, 1992.

[21] J. G. Muller, S. J. Paikoff, S. E. Rokita, and C. J. Burrows, "DNA modification promoted by water-soluble nickel (II) salen complexes: a switch to DNA alkylation," Journal of Inorganic Biochemistry, vol. 54, no. 3, pp. 199-206, 1994.

[22] J. G. Muller, S. J. Paikoff, S. E. Rokita, and C. J. T. Burrows, "Ligand-centered oxidation of nickel salen complexes in reaction with DNA," Abstracts of Papers of the American Chemical Society, vol. 208, p. 266, 1994.

[23] J. G. Muller, L. A. Kayser, S. J. Paikoff et al., "Formation of DNA adducts using nickel(II) complexes of redox-active ligands: a comparison of salen and peptide complexes," Coordination Chemistry Reviews, vol. 185-186, pp. 761-774, 1999.

[24] S. Routier, H. Vezin, E. Lamour, J. L. Bernier, J. P. Catteau, and C. Bailly, "DNA cleavage by hydroxy-salicylideneethylendiamine-iron complexes," Nucleic Acids Research, vol. 27, no. 21 , pp. $4160-4166,1999$. 
[25] C. C. Cheng and Y. L. Lu, "Novel water-soluble 4,4-disubstituted ruthenium(iii)-salen complexes in dna stranded scission," Journal of the Chinese Chemical Society, vol. 45, pp. 611-617, 1998.

[26] T. Tanaka, K. Tsurutani, A. Komatsu et al., "Synthesis of new cationic schiff base complexes of copper(II) and their selective binding with DNA," Bulletin of the Chemical Society of Japan, vol. 70, no. 3, pp. 615-629, 1997.

[27] A. Sigel and H. Sigel, Eds., Metal Ions in Biological Systems, vol. 32, 33, Dekker, New York, NY, USA, 1996.

[28] J. Tedim, S. Patrício, R. Bessada et al., “Third-order nonlinear optical properties of DA-salen-type nickel(II) and copper(II) complexes," European Journal of Inorganic Chemistry, no. 17, pp. 3425-3433, 2006.

[29] J. E. Reed, A. A. Arnal, S. Neidle, and R. Vilar, "Stabilization of G-quadruplex DNA and inhibition of telomerase activity by square-planar nickel(II) complexes," Journal of the American Chemical Society, vol. 128, pp. 5992-5993, 2006.

[30] A. A. Isse, A. Gennaro, and E. Vianello, "A study of the electrochemical reduction mechanism of $\mathrm{Ni}($ salophen) in DMF," Electrochimica Acta, vol. 37, no. 1, pp. 113-118, 1992.

[31] I. C. Santos, M. Vilas-Boas, M. F. M. Piedade, C. Freire, M. T. Duarte, and B. de Castro, "Electrochemical and X-ray studies of nickel(II) Schiff base complexes derived from salicylaldehyde. Structural effects of bridge substituents on the stabilisation of the +3 oxidation state," Polyhedron, vol. 19, no. 6, pp. 655-664, 2000.

[32] P. Vanalabhpatana and D. G. Peters, "Catalytic reduction of 1,6-dihalohexanes by nickel(I) salen electrogenerated at glassy carbon cathodes in dimethylformamide," Journal of the Electrochemical Society, vol. 152, no. 7, pp. E222-E229, 2005.

[33] I. Correia, A. Dornyei, T. Jakusch, F. Avecilla, T. Kiss, and J. C. Pessoa, "Water-soluble sal ${ }_{2}$ en- and reduced sal $_{2}$ en-type ligands: study of their $\mathrm{Cu}^{\mathrm{II}}$ and $\mathrm{Ni}^{\mathrm{II}}$ complexes in the solid state and in solution," The European Journal of Inorganic Chemistry, no. 14, pp. 2819-2830, 2006.

[34] O. Buriez, L. M. Moretto, and P. Ugo, "Ion-exchange voltammetry of tris (2,2' -bipyridine) nickel(II), cobalt(II), and Co(salen) at polyestersulfonated ionomer coated electrodes in acetonitrile: reactivity of the electrogenerated low-valent complexes," Electrochimica Acta, vol. 52, no. 3, pp. 958-964, 2006.

[35] P. Vanalabhpatana and D. G. Peters, "Stoichiometric reduction of secondary alkyl monohalides by electrogenerated nickel(I) salen in the presence of oxygen and water: prospects for the formation of ketones," Journal of Electroanalytical Chemistry, vol. 593, pp. 34-42, 2006.

[36] Y. Abe, H. Akao, Y. Yoshida et al., "Syntheses, structures, and mesomorphism of a series of $\mathrm{Ni}(\mathrm{II})$ salen complexes with 4substituted long alkoxy chains," Inorganica Chimica Acta, vol. 359, no. 10, pp. 3147-3155, 2006.

[37] X. Feng, Z. X. Du, B. X. Ye, and F. N. Cui, "Synthesis, Crystal Structure and Electrochemistry Properties of a (N,N'-Ethylene-bis(salicylaldiminato)) Nickel(II) Complex, $\left.\left[\mathrm{Ni}_{2} \text { (salen }\right)_{2}\right] \cdot \mathrm{NCS} \cdot \mathrm{NH}_{4}$," Chinese Journal of Structural Chemistry, vol. 26, no. 9, pp. 1033-1038, 2007.

[38] M. B. R. Bastos, "Contribution to the study electroanalytical of salen schiff bases and pyridoxal-5' -phosphate and some of its complexes with $\mathrm{Cu}^{2+}, \mathrm{Co}^{2+}, \mathrm{Ni}^{2+}$ and $\mathrm{UO}_{2}{ }^{2+}$, [Ph.D. thesis], Pontifical Catholic University of Rio de Janeiro, Brazil, 1997.

[39] P. A. M. Farias and M. B. R. Bastos, "Electrochemical behavior of copper(II) salen in aqueous phosphate buffer at the mercury electrode," International Journal of Electrochemical Science, vol. 4, no. 3, pp. 458-470, 2009.
[40] M. B. R. Bastos, J. C. Moreira, and P. A. M. Farias, "Adsorptive stripping voltammetric behaviour of $\mathrm{UO}_{2}$ (II) complexed with the Schiff base $\mathrm{N}, \mathrm{N}^{\prime}$ - ethylenebis(salicylidenimine) in aqueous 4-(2-hydroxyethyl)-1-piperazine ethanesulfonic acid medium," Analytica Chimica Acta, vol. 408, no. 1, pp. 83-88, 2000.

[41] R. Greef, Instrumental Methods in Electrochemistry, Ellis Horwood, Chichester, England, 1985.

[42] A. J. Bard and L. R. Faulkner, Electrochemical Methods: Fundamentals and Applications, John Wiley \& Sons, New York, NY, USA, 1980.

[43] A. A. Barros, J. A. Rodrigues, P. J. Almeida, P. G. Rodrigues, and A. G. Fogg, "Voltammetry of compounds confined at the hanging mercury drop electrode surface," Analytica Chimica Acta, vol. 385, no. 1-3, pp. 315-323, 1999.

[44] V. Cueillić, M. Mlakar, and M. Branica, "Influence of the HEPES Buffer on Electrochemical Reaction of the Copper(II)Salicylaldoxime Complex," Electroanalysis, vol. 10, no. 12, pp. 852-856, 1998.

[45] M. Lovric, S. Komorsky-Lovric, and R. W. Murray, "Adsorption effects in square-wave voltammetry of totally irreversible redox reactions," Electrochimica Acta, vol. 33, no. 6, pp. 739-744, 1988.

[46] R. Djogic and M. Branica, "Square-wave cathodic stripping voltammetry of hydrolyzed uranyl species," Analytica Chimica Acta, vol. 305, no. 1-3, pp. 159-164, 1995.

[47] S. Komorsky-Lovric and M. Lovric, "Kinetic measurements of a surface confined redox reaction," Analytica Chimica Acta, vol. 305, no. 1-3, pp. 248-255, 1995.

[48] M. Lovric and S. Komorsky-Lovric, "Square-wave voltammetry of an adsorbed reactant," Journal of Electroanalytical Chemistry, vol. 248, no. 2, pp. 239-253, 1988.

[49] B. K. Sweeny and D. G. Peters, "Cyclic voltammetric study of the catalytic behavior of nickel(I) salen electrogenerated at a glassy carbon electrode in an ionic liquid (1-butyl-3methylimidazolium tetrafluoroborate, $\left.\mathrm{BMIM}^{+} \mathrm{BF}_{4-}\right)$," Electrochemistry Communications, vol. 3, no. 12, pp. 712-715, 2001.

[50] F. Azevedo, C. Freire, and B. de Castro, "Reductive electrochemical study of $\mathrm{Ni}(\mathrm{II})$ complexes with $\mathrm{N}_{2} \mathrm{O}_{2}$ schiff base complexes and spectroscopic characterisation of the reduced species. Reactivity towards CO," Polyhedron, vol. 21, no. 17, pp. 1695-1705, 2002.

[51] M. F. S. Teixeira and T. R. L. Dadamos, "An electrochemical sensor for dipyrone determination based on nickel-salen film modified electrode," in Proceedings of the Eurosensors XXIII Conference, J. Brugger and D. Briand, Eds., vol. 1 of Procedia Chemistry, 2009.

[52] J. L. Li, F. Gao, Y. K. Zhang, and X. D. Wang, "Electrochemical polymerization of nano-micro sheaf/wire conducting polymer poly[Ni(SALEN)] for electrochemical energy storage system," Chinese Journal of Polymer Science, vol. 28, no. 5, pp. 667-671, 2010.

[53] C. S. Martin, T. R. L. Dadamos, and M. F. S. Teixeira, "Development of an electrochemical sensor for determination of dissolved oxygen by nickel-salen polymeric film modified electrode," Sensors and Actuators B, vol. 175, pp. 111-117, 2012. 

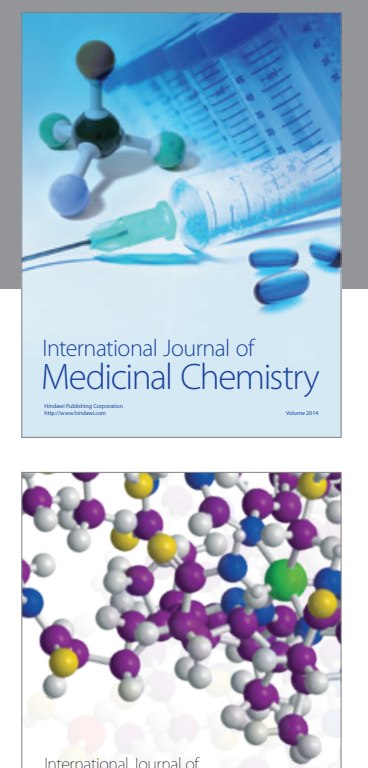

\section{Carbohydrate} Chemistry

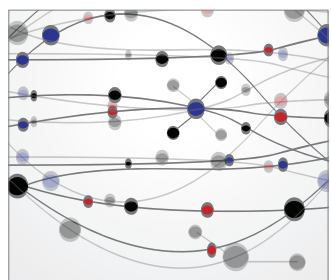

The Scientific World Journal
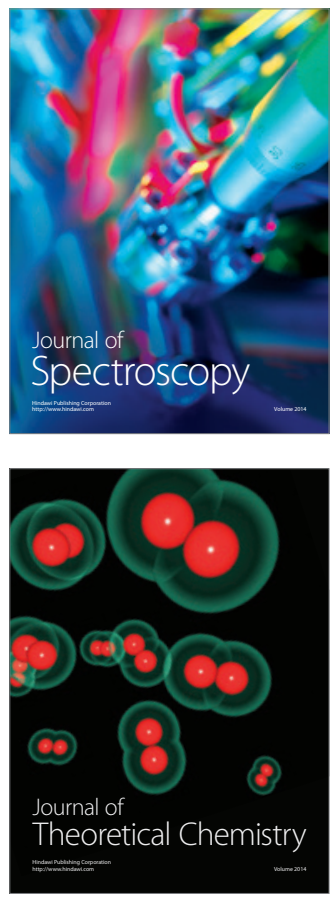
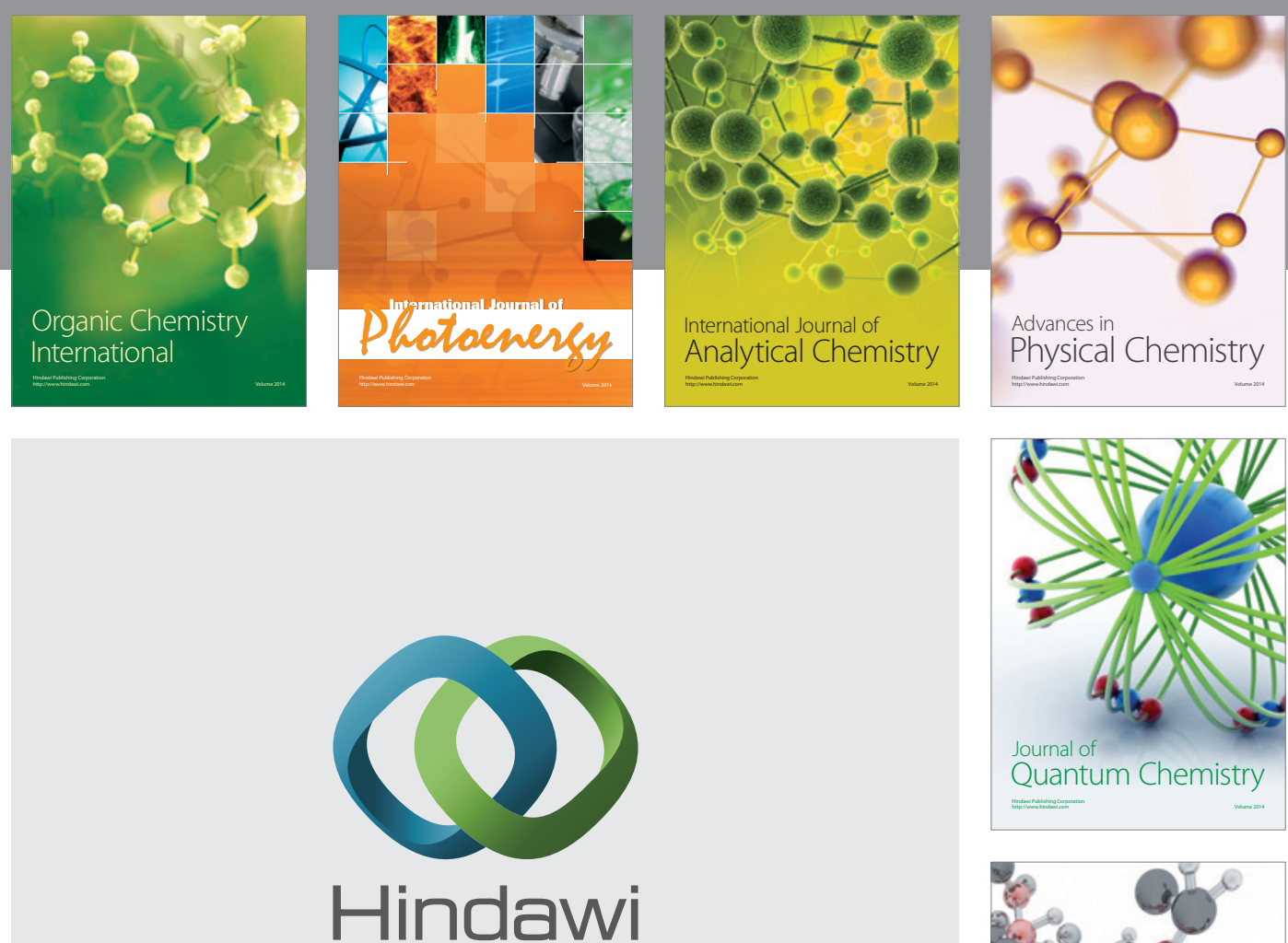

Submit your manuscripts at

http://www.hindawi.com

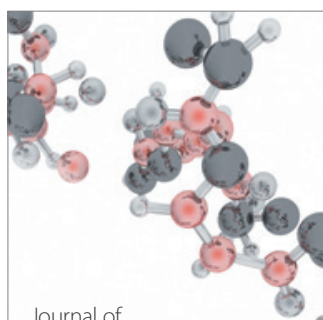

Analytical Methods

in Chemistry

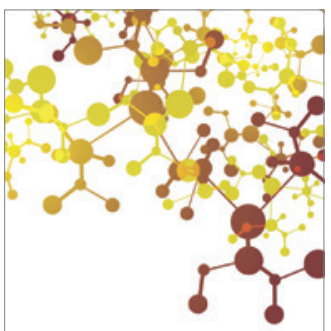

Journal of

Applied Chemistry

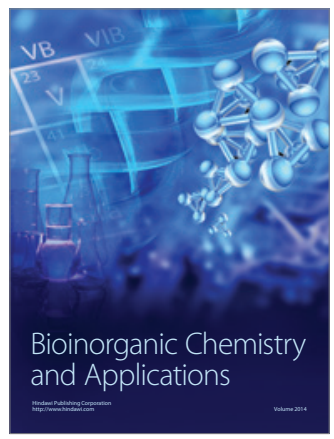

Inorganic Chemistry
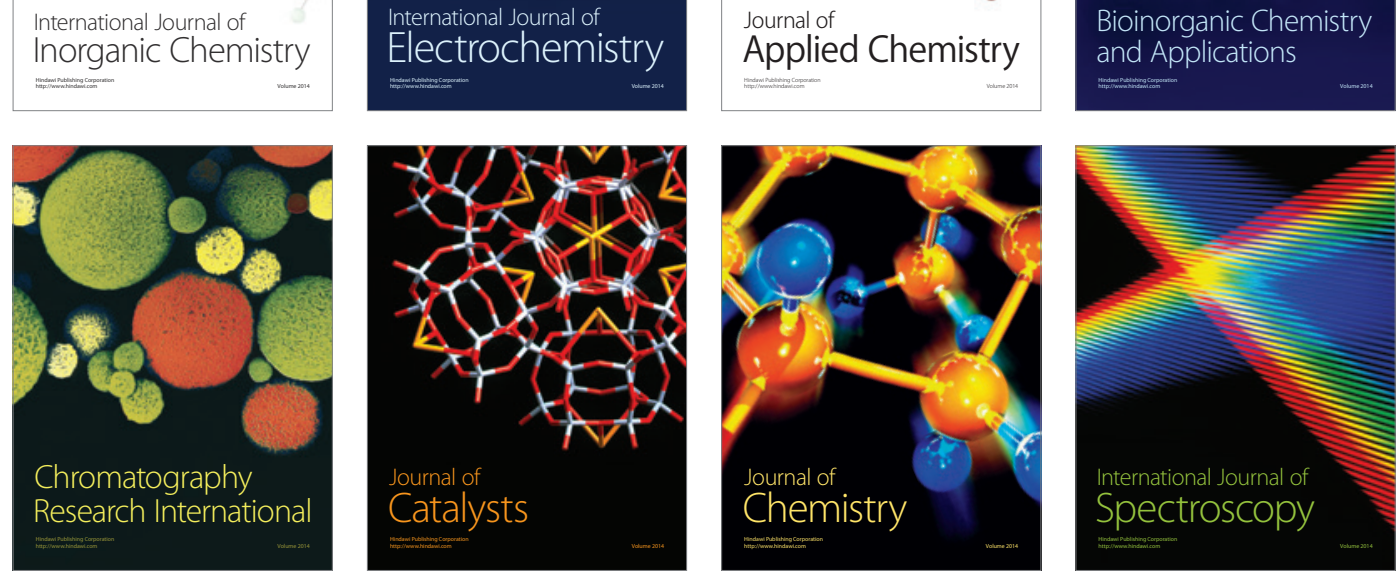